\title{
TINJAUAN YURIDIS ACFTA TERHADAP PEMBANGUNAN KELAUTAN DAN PERIKANAN
}

\author{
Radityo Pramoda \\ Balai Besar Penelitian Sosial Ekonomi Kelautan dan Perikanan \\ JI. KS. Tubun Petamburan VI Jakarta 10260 \\ Telp. (021) 53650162, Fax. (021)53650159 \\ Diterima 15 September 2011 -Disetujui 29 November 2011
}

\begin{abstract}
ABSTRAK
Agreement on Comprehensive Economic Co-operation between the Association of South East Asian Nations and the People's Republic of China (ACFTA), merupakan wujud kerjasama negara ASEAN dan China untuk membentuk kawasan perdagangan bebas. ACFTA sebagai salah satu instrumen diharapkan dapat meningkatkan daya saing ekonomi, serta menciptakan kemakmuran rakyat Indonesia. Berdasarkan hal tersebut, tulisan ini bertujuan mengkaji kesepakatan ACFTA dan melakukan tinjauan yuridis terhadap pembangunan kelautan dan perikanan. Hasil kajian menunjukkan, bahwa ACFTA merupakan kerjasama perdagangan bebas untuk menurunkan tarif bea masuk dan secara yuridis mempengaruhi komponen sistem hukum (substansi, struktural, dan budaya hukum) di dalam melindungi produk di sektor kelautan dan perikanan
\end{abstract}

Kata kunci: Tinjauan yuridis, ACFTA, pembangunan kelautan dan perikanan

\section{PENDAHULUAN}

\begin{abstract}
Kesepakatan Kawasan Perdagangan Bebas/Free Trade Area (FTA) antara negara Asia Tenggara/ASEAN dengan Republik Rakyat China, ditandatangani tanggal 4 November 2002, di Phnom Phen, Kamboja yang dituangkan dalam Framework Agreement on Comprehensive Economic Co-operation between the Association of South East Asian Nations and the People's Republic of China (ACFTA). Kesepakatan ini merupakan lanjutan kerjasama ASEAN-China Comprehensive Economic Cooperation (CEC) yang merupakan kesepakatan pemimpin negara ASEAN di Bandar Seri Begawan, Brunei Darussalam, tanggal 6 November 2001. Ratifikasi ACFTA dilakukan pada tanggal 15 Juni 2004, melalui Keputusan Presiden (Keppres) Republik Indonesia No. 48 Tahun 2004. Menurut Keppres setelah ratifikasi ACFTA (29 November 2004), para menteri ekonomi ASEAN dan China menandatangani Agreement Trade in Goods dan Agreement Dispute Settlement Mechanism di Vientiane, Laos.
\end{abstract}

Tujuan penandatanganan ACFTA adalah: (a) memperkuat dan meningkatkan kerjasama perdagangan, serta investasi antara anggota ASEAN dan China; (b) meliberalisasikan secara progresif serta meningkatkan perdagangan barang, jasa, menciptakan suatu sistem yang transparan, dan mempermudah investasi; (c) menggali bidang kerjasama baru dan mengembangkan kerjasama ekonomi diantara para anggota ASEAN dan China; (d) memfasilitasi integrasi ekonomi yang lebih efektif dengan negara anggota baru ASEAN (Kamboja, Laos, Myanmar, dan Vietnam), dalam menjembatani kesenjangan pembangunan ekonomi antara para anggota. Rencana penurunan atau pengurangan tarif bea masuk yang disepakati di dalam ACFTA, dilaksanakan menjadi tiga tahapan: (a) Early Harvest Programme (EHP); (b) penurunan tarif bea masuk untuk produk yang masuk kategori normal track (normal track 1 dan normal track 2); (c) penurunan tarif bea masuk terhadap produk sensitive dan highly sensitive.

Ilustrasi ini tidak hanya mengandalkan kesiapan peran pemerintah, akan tetapi menuntut pula kesiapan semua pelaku dunia usaha. Hal ini didasarkan adanya keterbukaan pasar seluas-luasnya, yang menyebabkan impor barang dan jasa negara lain dapat mengalir secara bebas. Kerugian yang mungkin timbul sebagai akibat adanya kesepakatan ACFTA, sedapat mungkin perlu diminimalisir sejak dini atau bahkan ditiadakan sama sekali. ACFTA, telah menjadi komitmen penting bagi pemerintah Indonesia dengan mitra dialognya untuk melangkah menjadi negara maju. Persiapan Indonesia menghadapi ACFTA di sektor kelautan dan perikanan (KP), sesungguhnya sudah dapat dilakukan sejak tahun 2002. Dalam rentang waktu yang cukup panjang tersebut, upaya untuk mempersiapkan pelaksanaannya belum terlihat maksimal. Ketidaksiapan ini terlihat dengan tidak adanya peningkatan daya saing untuk menghilangkan ekonomi biaya tinggi, penyediaan sumber daya manusia (SDM) yang kompeten, kesiapan penataan regulasi serta kebijakan. Pembenahan hukum di sektor KP selama ini juga dirasakan masih belum memberikan hasil yang memadai.

Menurut Brotosusilo dalam Cahyadi dan Danardono (2009), jika perbaikan kondisi hukum terjadi setelah ratifikasi, berarti kaidah hukum internasional memberikan pengaruh lebih dominan daripada sistem hukum nasional. Demikian halnya, dengan kesan pemerintah yang kurang menganggap serius ranah ini dan merasa telah siap menghadapi era perdagangan bebas regional. Banyak kalangan mengkhawatirkan pemberlakuan ACFTA, terutama produk olahan perikanan 
dari China bisa masuk secara bebas dengan harga murah, sehingga dapat mengancam daya saing produk perikanan Indonesia. Keikutsertaan Indonesia dalam ACFTA memberikan pengaruh kepada perekonomian nasional yang berdampak pada kesejahteraan masyarakat. Berdasarkan paparan tersebut, tulisan ini bertujuan untuk memahami kesepakatan ACFTA, serta mengkajinya dalam sudut pandang yuridis terhadap pembangunan Kelautan dan Perikanan.

\section{KESEPAKATAN ACFTA}

Prinsip dasar disepakatinya ACFTA adalah semua pihak yang terlibat mendapatkan manfaat. Adanya penghapusan semua atau sebagian hambatan perdagangan, diharapkan dapat memberikan keuntungan yang sama besarnya bagi negara yang terlibat. Artinya, terdapat keadaan berimbang antara kemudahan yang diberikan dan yang akan diterima. Negara yang terikat kesepakatan ACFTA telah menyepakati untuk memperkuat dan meningkatkan kerjasama ekonomi melalui: (a) penghapusan tarif dan hambatan non tarif dalam perdagangan; (b) liberalisasi secara progresif perdagangan jasa; (c) membangun rezim investasi yang kompetitif dan terbuka dalam kerangka ASEAN-China Free Trade Area (FTA).

Terdapat tiga (3) skenario dalam penurunan dan penghapusan tarif perdagangan barang yang disepakati: (a) EHP programme; (b) normal track programme; (c) sensitive track programme. Tujuan skenario EHP, adalah untuk mempercepat implementasi penurunan tarif produk. Menurut Surat Edaran No. SE-10/BC/2005, tentang Petunjuk Pelaksanaan Penetapan Tarif Bea Masuk atas Barang Impor dalam Rangka Early Harvest Package (EHP) ASEAN-China Free Trade Area (FTA) dan dalam Rangka EHP Bilateral Indonesia-China FTA, skema program penurunan tarif EHP dimulai 1 Januari 2004 dan dalam waktu tiga (3) tahun, tarif diturunkan secara bertahap menjadi $0 \%$ di tahun 2006. Produk yang termasuk kategori EHP berdasarkan ACFTA (Article 3 (a), (i)), tercantum pada Tabel 1.

Penurunan tarif bea masuk berdasarkan skenario normal track programme (Tabel 2), menurut
Tabel 1. Produk Early Harvest Package.

\begin{tabular}{cl}
\hline Bab & \multicolumn{1}{c}{ Deskripsi } \\
\hline 01 & Hewan hidup \\
02 & Daging dan produk daging dikonsumsi \\
03 & Ikan \\
04 & Produk susu \\
05 & Produk hewan lainnya \\
06 & Pohon hidup \\
07 & Sayuran dikonsumsi \\
08 & Buah-buahan dikonsumsi dan kacang- \\
& kacangan \\
\hline
\end{tabular}

Peraturan Menteri Keuangan No. 56/PMK.010/2005, tentang Program Penurunan/Penghapusan Tarif Bea Masuk dalam Rangka Normal Track Asean-China Free Trade Area (AC-FTA) mencakup: (a) normal track 1 berupa penurunan tarif bea masuk pada tahun 2010 menjadi 0\%; (b) normal track 2 berupa penurunan tarif bea masuk pada tahun 2012 menjadi 0\%.

\section{*) Normal Track 2}

Pengurangan tarif bea masuk yang termasuk skenario ketiga (sensitive track programme), dibagi menjadi:

a. Sensitive list.

Produk yang masuk kategori ini dibagi dalam dua tahapan reduksi tarif bea masuk:

- Tahun 2012: tarif bea masuk menjadi 20\% (terdapat 5 produk perikanan);

- Tahun 2018: tarif bea masuk menjadi 0\% - 5\% (terdapat 4 produk perikanan).

b. Highly sensitive list.

Produk yang masuk dalam katregori ini pada tahun 2015, menjadi 50\% (bagi produk yang pada tahun 2002 mempunyai tingkatan tarif $>50 \%$ ).

Preferensi penurunan tarif untuk dapat melaksanakan ketiga skenario program yang diperjanjikan dalam ACFTA, dilakukan melalui Certificate

Tabel 2. Normal Track ASEAN-China FTA.

\begin{tabular}{|c|c|c|c|c|c|c|c|c|}
\hline \multirow{2}{*}{ Tarif $(=\mathrm{X})$} & \multicolumn{8}{|c|}{ Normal Track ASEAN-China FTA } \\
\hline & 2005 & 2006 & 2007 & 2008 & 2009 & 2010 & 2011 & 2012 \\
\hline$x>20 \%$ & 20 & 20 & 12 & 12 & 5 & $0 / 5^{*}$ & $0 / 5^{*}$ & $0 / 0^{*}$ \\
\hline $5 \% \leq X<20 \%$ & 15 & 15 & 8 & 8 & 5 & $0 / 5^{*}$ & $0 / 5^{*}$ & $0 / 0^{*}$ \\
\hline $10 \% \leq X<15 \%$ & 10 & 10 & 8 & 8 & 5 & $0 / 0$ & $0 / 0$ & $0 / 0^{*}$ \\
\hline $5 \%<X<10 \%$ & 5 & 5 & 5 & 5 & 0 & 0 & 0 & $0 / 0^{*}$ \\
\hline \multirow{2}{*}{$x \leq 5 \%$} & tetap/ & tetap/ & tetap/ & tetap/ & \multirow{2}{*}{0} & \multirow{2}{*}{0} & \multirow{2}{*}{0} & \multirow{2}{*}{$0 / 0^{*}$} \\
\hline & standstill & standstill & standstill & standstill & & & & \\
\hline
\end{tabular}


of Origin/Surat Keterangan Asal Barang (SKA). Menurut Peraturan Menteri Perdagangan No. 43/M-DAG/ PER/10/2007, tentang Penerbitan Surat Keterangan Asal (Certificate of Origin) untuk Barang Ekspor Indonesia, SKA merupakan dokumen yang disertakan pada waktu barang ekspor Indonesia memasuki wilayah negara tertentu, yang membuktikan bahwa barang tersebut berasal, dihasilkan, dan/atau diolah di Indonesia.

Berdasarkan Agreement on Trade in Goods of the Framework Agreement on Comprehensive Economic Cooperation between the Association of Southeast Asian Nations and the People's Republic of China, Annex 3: Rules of Origin for the ASEAN-China Free Trade Area (Rule 4 (b)), formulasi penetapan local content yang disepakati yaitu: tidak sewenang-wenang. Segala kebijakan yang terkait dengan perdagangan harus dilengkapi mekanisme tinjauan kebijakan secara periodik.

\section{TINJAUAN YURIDIS}

Penandatanganan ACFTA oleh Indonesia, tidak dapat dipisahkan dengan kaedah hukum kebiasaan internasional dalam Konvensi Wina 1969. Konvensi Wina 1969, merupakan kodifikasi hukum internasional yang berlaku di lingkungan masyarakat internasional. Walaupun Indonesia belum meratifikasi Konvensi Wina 1969, kaedahnya dapat dijadikan panduan bagi hukum kebiasaan internasional. O'Connell dalam

$\frac{\text { Value of non-ACFTA materials + Value of materials of undetermined origin }}{\text { FOB price }}$
Therefore, the ACFTA content: $100 \%$ - non-ACFTA material = at least $40 \%$

Menurut formulasi penetapan local content tersebut, apabila hasil perhitungan rumus di atas kurang $60 \%$, maka produk tersebut akan mendapatkan konsesi. Berdasarkan hal tersebut, kandungan lokal atau ACFTA content sekurang-kurangnya adalah $40 \%$.

Beberapa prinsip dasar yang terkandung di dalam kesepakatan ACFTA:

\section{Most Favourite Nation (MFN)}

Prinsip non-diskriminasi yang memberi perlakuan sama kepada semua mitra dialog ACFTA. Pengertian dasarnya bahwa pemberian keringanan tarif bea masuk terhadap produk suatu negara, harus diberlakukan juga kepada semua negara mitra dagang ACFTA. Prinsip MFN dapat disimpangi terhadap negara di luar ACFTA, yaitu diperbolehkan tidak memberikan preferensi yang sama atas penurunan tarif bea masuk.

\section{National Treatment}

Prinsip ini melarang diskriminasi perlakuan terhadap subjek hukum nasional dengan subjek hukum negara lain. Negara dalam kelompok ACFTA, diwajibkan memberikan perlakuan sama atas barang impor dan lokal. Prinsipnya, apabila produk impor telah masuk dalam wilayah suatu negara, maka produk tersebut harus mendapat perlakuan sama dengan produk domestik.

\section{Transparency}

Prinsip ini mengharuskan negara yang menyepakati ACFTA, untuk bersifat terbuka mengenai berbagai kebijakan dalam usaha perdagangan. Negara anggota dalam mendukung prinsip ini, wajib menerapkan peraturan perdagangannya secara adil dan
Kusumohamidjojo (1986), menyatakan ratification is only required when the treaty so specifies or so implies. Berdasarkan Konvensi Wina 1969 (Article 2), ratification mean in each case the international act so named whereby a state establishes on the international plane its consent to be bound by a treaty. Alur proses ratifikasi Pemerintah Indonesia terhadap ACFTA melalui Keppres No. 48 Tahun 2004 dapat dilihat pada Gambar 2.

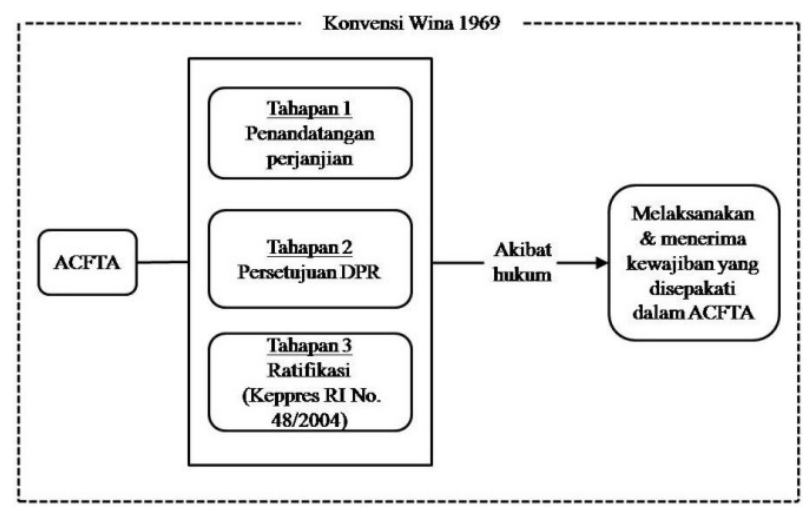

Gambar 2. Alur Kesepakatan ACFTA.

Berdasarkan Gambar 2 diketahui bahwa ratifikasi merupakan tahapan ketiga yang harus dilalui dalam persetujuan internasional agar mempunyai kekuatan mengikat. Dua tahapan yang harus dijalani sebelumnya, adalah penandatanganan dan persetujuan DPR dengan ketentuan konstitusional tiap negara. Dilaluinya ketiga tahapan tersebut, memberikan akibat hukum tersendiri yang harus ditaati oleh Indonesia. Akibat hukum ini memberikan konsekuensi untuk menerima segala kewajiban yang dibebankan, serta merubah hukum nasional sesuai dengan ketentuan di dalam ACFTA. 
Implementasinya memerlukan jaminan penerapan secara konsisten dan harus efektif daya berlakunya.

Peran hukum di sektor KP terhadap ACFTA, merupakan peran yang fundamental dan tidak bisa diabaikan. Kepentingan hukum akan selalu mengikuti setiap transaksi dagang atau bisnis, baik yang dilakukan sesama anggota ACFTA maupun pihak lain. Pengabaian kepentingan hukum membawa dampak terhadap tindakan pedagang, pemerintah, maupun masyarakat KP sebagai warga negara, yang dapat mengganggu sistem perekonomian. Tugas pemerintah (lingkup nasional) dalam menindaklanjuti ratifikasi ACFTA, khususnya di sektor KP meliputi pembenahan seluruh komponen sistem hukum. Komponen sistem hukum menurut paradigma Friedman (2009), terdiri substansi, struktural, dan budaya hukum.

\section{KOMPONEN SUBSTANSI}

Komponen substansi sistem hukum adalah hasil nyata yang diterbitkan berupa aturan, baik yang tertulis maupun tidak tertulis. Menurut Yuswanto (2011), negara maupun administrasi negara pada dasarnya membuat dua macam bentuk keputusan, yaitu peraturan perundang-undangan dan keputusan yang bukan peraturan perundang-undangan. Pembenahan komponen substansi sistem hukum, berkaitan dengan pembentukan hukum nasional yang disesuaikan dengan kesepakatan di dalam ACFTA. Pembenahan substansi sistem hukum ini berupa penyempurnaan undangundang (UU) yang belum memenuhi tuntutan, maupun membuat UU baru yang belum ada pengaturannya (sepanjang diperjanjikan di dalam kesepakatan ACFTA). Kurangnya perhatian terhadap pemahaman substansi pada awal peratifikasian ACFTA, telah menimbulkan kesulitan bagi Indonesia pada saat pemberlakuannya.

Menurut prediksi para pelaku bisnis serta pemerhati ekonomi Indonesia, ACFTA dapat melemahkan ketahanan ekonomi nasional terhadap serangan produk China. Kondisi ini menyebabkan, tanggung jawab moril bagi para perumus kebijakan sektor KP kini jauh lebih berat. Perumusan peraturan yang memberikan jaminan mutu dan keamanan terhadap produk perikanan Indonesia, merupakan salah satu upaya agar dapat bersaing dalam ACFTA. Pembenahan komponen substansi sistem hukum di bidang $\mathrm{KP}$, wajib dilandasi adanya kepentingan memberdayakan masyarakatnya. Pembenahan komponen substansi sistem hukum selama ini, dirasakan masih ada campur tangan pihak tertentu yang mempunyai kepentingan dengan penyempurnaan atau dibuatnya suatu aturan. Campur tangan tersebut, tidak jarang menimbulkan kesulitan bagi pihak yang merumuskan kebijakan dan bahkan ada yang merugikan masyarakat KP itu sendiri.

Pemberdayaan seluruh strata komponen masyarakat KP perlu dilakukan, mengingat adanya potensi yang besar apabila mengikutsertakan mereka. Pemerintah dituntut dapat merumuskan substansi sistem hukum nasional, yang tidak berpihak kepada salah satu pihak saja. Tuntutan ini memerlukan kecermatan dan kelihaian perumus kebijakan, guna menyempurnakan sistem hukum yang ada ataupun menciptakan produk hukum. Penyempurnaan hukum di sektor KP memerlukan SDM yang handal. Keahlian mutlak dibutuhkan untuk dapat merumuskan substansi sistem hukum yang mudah dipahami, serta tidak ada celah untuk disimpangi/disalahgunakan. Konsekuensinya, memberikan tugas kepada komponen struktural sistem hukum di sektor KP untuk mengawal dan mengantisipasinya sesuai dengan hasil kesepakatan ACFTA.

\section{KOMPONEN STRUKTURAL}

Komponen struktural sistem hukum merupakan bagian yang bergerak dalam suatu mekanisme, serta merupakan lembaga yang berkaitan erat dengan sistem hukum. Lembaga yang dimaksud adalah pembuat undang-undang, pengadilan, kepolisian, kejaksaan, kehakiman, dan lembaga hukum lainnya. Kinerja lembaga yang ada saat ini masih perlu untuk disinergikan lagi. Komponen struktural sistem hukum harus disesuaikan serta disempurnakan berdasarkan hasil kesepakatan ACFTA. Penyempurnaan ini dapat terlaksana apabila disertai dengan tanggung jawab penuh dan peningkatan kompetensi SDM yang dimiliki, dalam mengelola lembaga terkait. Adanya prosedur perizinan yang menyulitkan, aturan yang tumpang tindih, serta biaya tambahan untuk mendapatkan kemudahan dan fasilitas lembaga terkait selama ini, menyebabkan ekonomi biaya tinggi (high cost economy).

MenurutErwiningsih (2011), segala aktivitas aparat pemerintah harus tetap dalam kendali pengawasan yang memadai. Keberadaan aparat pemerintah yang selalu dalam pengawasan, mengandung makna bahwa mereka harustundukpadahukum. Upayalainuntukmeningkatkan penyelenggaraan pemerintah adalah dengan mengefektifkan pengawasan lembaga peradilan maupun masyarakat, berdasarkan asas umum pemerintahan yang baik. Kinerja lembaga yang tidak sesuai bagi peningkatan efisiensi harus segera dioptimalkan, agar tidak menjadi hambatan bagi aktivitas ekonomi. Kalangan masyarakat usaha KP juga memerlukan kepastian hukum, keadilan, dan jaminan apabila terjadi sengketa maupun gangguan terhadap investasinya dalam melakukan perdagangan.

Sulistiyono dan Rustamaji (2009) menyatakan kelemahan utama bidang hukum yang sering dihadapi oleh pelaku ekonomi di Indonesia adalah kepastian hukum. Pembuatan kebijakan diperlukan dalam rangka menjamin konsistensi tindakan administrasi. Kebutuhan akan konsistensi ini berkaitan dengan salah satu asas umum penyelenggaraan pemerintah 
yang layak, yaitu kepastian hukum. Kepastian hukum sangat dibutuhkan untuk memperhitungkan dan mengantisipasi resiko. Kelemahan dalam kepastian hukum telah menyebabkan pemberdayaan usaha KP selama ini dirasakan belum optimal, dan masih memerlukan kerjasama lembaga terkait. Setiap lembaga pada dasarnya mempunyai karakteristik yang berbeda, namun antara satu dan yang lainnya saling menunjang (komplementer).

\section{KOMPONEN BUDAYA HUKUM}

Budaya hukum menurut Friedman (2009), yaitu sikap manusia terhadap hukum dan sistem hukumkepercayaan, nilai, pemikiran, serta harapannya. Pendapat tersebut memaknai budaya hukum sebagai suasana pikiran sosial dan kekuatan sosial yang menentukan bagaimana hukum digunakan, dihindari, atau disalahgunakan. Budaya hukum menentukan bagaimana seharusnya hukum itu berperilaku pada sikap dan sistem nilai di dalam masyarakat. Reaksi masyarakat terhadap penerapan kesepakatan ACFTA membawa pengaruh terhadap sistem nilai yang dianutnya. Pembenahan komponen budaya hukum tercermin dalam sikap masyarakat yang sangat dipengaruhi nilai yang dianut. Upaya pembenahan budaya hukum dalam sistem hukum, dapat dilihat melalui cara pandang masyarakat Indonesia terhadap sistem nilai yang dominan pada kegiatan bisnis. Keberadaan nilai tersebut tidak dapat berdiri sendiri, tetapi selalu terwujud dalam antinomi, yaitu pasangan nilai diantara pasangan tersebut seringkali saling bertegangan (tetapi tidak selalu bertentangan).

Sistem nilai yang dianut masyarakat ditinjau secara hukum, merupakan jalinan yang serasi antara pasangan nilai tersebut. Pada dunia bisnis, antinomi pasangan nilai yang menonjol antara lain: materialisme-spiritual, individualisme-komunalisme, dan inovasi-konservasi (Brotosusilo dalam Cahyadi dan Danardono, 2009). Terdapat dua hasil penelitian sistem nilai: (a) penelitian Soepomo, bahwa yang serasi bagi masyarakat Indonesia apabila komunalisme lebih dominan daripada individualisme; (b) penelitian Brenner, bahwa yang serasi bagi sebagian masyarakat apabila spiritualisme lebih dominan daripada materialisme. Pendapat Grotius dalam Cahyadi dan Danardono (2009), menyatakan di dalam hukum barat maupun hukum internasional keberadaan nilai individualisme lebih menonjol daripada nilai komunalisme. Produk hukum yang mengacu kepada sistem nilai individualisme, apabila dihadapkan pada masyarakat yang menganut sistem nilai dan budaya hukum yang berbeda, penerapannya akan menjumpai banyak kesulitan.

Proses menanamkan nilai individualisme tersebut akan berlangsung lama, sebelum akhirnya tercapai suatu keadaan yang mapan. Prinsip yang terkandung dalam kesepakatan ACFTA sebagaimana hukum internasional pada umumnya dilandasi pada pandangan yang menunjukan nilai materialisme lebih dominan daripada nilai spiritualisme. Berdasarkan pengalaman budaya antara nilai spiritualisme dengan nilai materialisme, pada akhirnya yang lebih mendominasi adalah materialisme. Tanpa adanya intervensi tertentu, pergulatan itu biasanya berlangsung untuk jangka waktu yang panjang dengan pengorbanan yang tidak kecil (Brotosusilo dalam Cahyadi dan Danardono, 2009). Pandangan nilai materialisme sebagai akibat kesepakatan ACFTA, terlihat adanya prinsip perlindungan Hak atas Kekayaan Intelektual (HaKI). Pemberlakuan ACFTA diprediksi akan menyulitkan pemerintah untuk melindungi produk dalam negeri dari sisi HaKI, terutama untuk produk hasil KP. Salah satu penyebabnya adalah masih banyaknya kalangan usaha KP yang meniru produk merek asing.

Menurut Rahardjo (2010), kehidupan sosial masyarakat Indonesia berputar pada sumbu nilai komunal. Sifat komunalisme terlihat dengan adanya perasaan bangga jika membagi hasil penemuannya kepada orang lain, dan tidak mempersoalkan jika orang lain meniru temuannya. Sifat yang demikian dirasakan dapat menghambat serta kurang sesuai dengan konsep perlindungan HaKI. Hal tersebut mengakibatkan pelaksanaan produk hukum yang berkaitan dengan perlindungan HaKI pada produk perikanan akan menghadapi hambatan. Abdurrahman (2009) menyatakan kegagalan mewujudkan salah satu nilai bukan hanya berdampak pada munculnya sistem hukum yang tidak baik, melainkan hukum yang dibuat menjadi tidak bermakna bagi masyarakat yang bersangkutan. Upaya mengatasinya, pemerintah sudah harus melakukan pemberian advokasi bagi pengusaha sektor KP lokal, khususnya usaha kecil dan menengah (UKM).

\section{KESIMPULAN}

ACFTA merupakan bentuk kerjasama liberalisasi ekonomi yang menyepakati penurunan tarif bea masuk, untuk meningkatkan perdagangan dan kerjasama investasi dalam kerangka perdagangan bebas. Penetapkan kebijakan strategis untuk menciptakan iklim usaha kondusif dan saling menguntungkan, baik bagi negara yang menyepakati ACFTA maupun pelaku usaha di dalam negeri, diperlukan studi kelayakan penerapannya. Tinjauan yuridis, ratifikasi ACFTA memberikan tanggung jawab besar KKP guna membenahi komponen substansi, struktural, dan budaya hukum, yang implementasinya dilakukan secara konsisten dalam koridor kepentingan yang disepakati. Upaya yang dapat dilakukan untuk menyikapi pengaruh adanya kesepakatan ACFTA, adalah dengan merumuskan kebijakan yang mandiri tanpa adanya intervensi pihak lain; menyederhanakan prosedur perizinan; membangun koordinasi dan kerjasama yang baik 
secara berkelanjutan antar lembaga terkait; serta memberikan bantuan dan perlindungan hukum bagi pengusaha UKM lokal Kelautan dan Perikanan.

\section{DAFTAR PUSTAKA}

Abdurrahman, M. 2009. Sosiologi dan Metode Penelitian Hukum. UMM Press. Malang.

Anonimous. 1969. Vienna Convention on the Law of Treaties. Vienna.

2002. Framework Agreement on Comprehensive Economic Co-operation between the Association of South East Asian Nations and the People's Republic of China, Phnom Penh.

2004. Agreement on Trade in Goods of the Framework Agreement on Comprehensive Economic Co-operation between the Association of Southeast Asian Nations and the People's Republic of China, Vientiane-Laos.

. 2004. Keputusan Presiden Republik Indonesia No. 48 Tahun 2004, tentang Pengesahan Framework Agreement on Comprehensive Economic Co-operation between the Association of South East Asian Nations and the People's Republic of China (Persetujuan Kerangka Kerja Mengenai Kerjasama Ekonomi Menyeluruh antara NegaraNegara Anggota Asosiasi Bangsa-Bangsa Asia Tenggara dan Republik Rakyat China). Jakarta.

2005. Peraturan Menteri Keuangan Republik Indonesia No. 56/PMK.010/2005, tentang Program Penurunan/Penghapusan Tarif Bea Masuk dalam Rangka Normal Track AseanChina Free Trade Area (AC-FTA). Jakarta.
2007. Peraturan Menteri Perdagangan No. 43/M-DAG/PER/10/2007, tentang Penerbitan Surat Keterangan Asal (Certificate of Origin) untuk Barang Ekspor Indonesia. Jakarta.

2005. Surat Edaran No. SE-10/BC/2005, tentang Petunjuk Pelaksanaan Penetapan Tarif Bea Masuk atas Barang Impor dalam Rangka Early Harvest Package (EHP) ASEAN-China Free Trade Area (FTA) dan dalam Rangka EHP Bilateral Indonesia-China FTA. Jakarta.

Cahyadi, A. dan D. Danardono. 2009. Sosiologi Hukum dalam Perubahan. Yayasan Obor Indonesia. Jakarta.

Erwiningsih, W. 2011. Peranan Hukum Pertanggung jawaban Perbuatan Pemerintah (Suatu Kajian dalam Kebijakan Pembangunan Hukum). http://eprints.ums.ac.id/330/1/6._WINAHYU. pdf. Diakses tanggal: 13 Juli 2011.

Friedman, L.M. 2009. Sistem Hukum: Perspektif IImu Sosial. Nusa Media. Bandung.

Kusumohamidjojo, B. 1986. Suatu Studi Aspek Operasional (Konvensi Wina Tahun 1969 tentang Hukum Perjanjian Internasional). Binacipta. Bandung.

Rahardjo, H.M. 2010. Jenis dan Metode Penelitian Kualitatif.http://mudjiarahardjo.com/ artikel/215.html?task=view.html. Diakses pada tanggal 5 Oktober 2010.

Sulistiyono, A. dan M. Rustamaji. 2009. Hukum Ekonomi sebagai Panglima. Masmedia Buana Pustaka. Sidoarjo-Jawa Timur .

Yuswanto. 2011. Peraturan Kebijakan. http:// www.politikindonesia.com/m/index. php?ctn=1\&k=pendapat $\& \mathrm{i}=28276$. Diakses pada tanggal: 13 Juli 2011. 